\title{
PENINGKATAN KONEKSI MATEMATIS PADA MATERI TRANSFORMASI GEOMETRI MENGGUNAKAN STRATEGI PEMBELAJARAN REACT BERBANTUAN MEDIA MOTIF BATIK KELAS XI IPS 1 SMA NEGERI 7 YOGYAKARTA
}

\author{
Ida Lydiati \\ Pendidik SMA Negeri 7 Yogyakarta \\ lydiati@seveners.com
}

\begin{abstract}
Abstrak: Penelitian ini bertujuan untuk mengetahui bagaimana cara meningkatkan kemampuan koneksi matematis peserta didik pada materi Transfomasi Geometri melalui strategi REACT menggunakan media motif batik pada kelas XI IPS 1 SMA Negeri 7 Yogyakarta. Penelitian ini adalah penelitian tindakan kelas yang dilaksanakan selam dua siklus. Setiap siklus terdiri atas tahap perencanaan (planning), tindakan (action), pengamatan (observation), dan refleksi (reflection). Hasil penelitian menunjukkan bahwa untuk meningkatkan koneksi matematis peserta didik dapat dilakukan dengan cara: (a) relating, peserta didik diberi kesempatan untuk mengaitkan materi yang dipelajari dalam Transformasi Geometri dengan kehidupan sehari-hari melalui contoh yang nyata dalam Lembar Kegiatan Peserta Didik memuat motif geometri dalam batik Yogyakarta. Setiap peserta didik didorong untuk mengemukakan pendapat dalam menyelesaikan masalah, baik secara tertulis maupun lisan; (b) experiencing, peserta didik dibiasakan membangun pengetahuan/konsep sendiri melalui proses kegiatan belajar dan materi ajar yang telah disiapkan; (c) applying, peserta didik dilatih menerapkan konsep untuk menyelesaikan suatu masalah Matematika maupun masalah dari kehidupan sehari-hari peserta didik; (d) cooperating, peserta didik dilatih membuat kesepakatan untuk menentukan penyelesaian terbaik. Jika terdapat perbedaan pendapat pada tugas individu atau tugas kelompok maka setiap anggota kelompok harus berperan aktif dalam mencapai tujuan pembelajaran; (e) transferring, peserta didik menggunakan pengetahuan yang dimilikinya dalam konteks baru melalui penerapan konsep yang diperoleh baik dalam masalah Matematika atau dalam kehidupan nyata dikaitkan dengan motif batik Yogyakarta.

Kata kunci: kemampuan koneksi matematis, strategi pembelajaran REACT, media motif batik
\end{abstract}

\section{ENHANCING THE MATHEMATICAL CONNECTION ABILITIES ON GEOMETRY TRANSFORMATION BY REACT LEARNING STRATEGY USING BATIK PATTERN MEDIA XI IPS 1 SMA NEGERI 7 YOGYAKARTA} Abstract: This study aims to find out how to improve students' mathematical connection abilities in the
Geometry Transformation material through the REACT strategy using batik motif media in class XI IPS
I of SMA Negeri 7 Yogyakarta. This research is a classroom action research conducted during two cycles.
Each cycle consists of planning, action, observation, and reflection. The results showed that to improve
students' mathematical connections can be done by: (a) relating, students are given the opportunity to link
the material studied in Geometry Transformation with everyday life through real examples in the Student
Activity Sheet containing geometric motifs in Yogyakarta batik. Every student is encouraged to express
their opinions in solving problems, both in writing and orally; (b) experiencing, students are accustomed
to building their own knowledge / concepts through the process of learning activities and teaching
materials that have been prepared; (c) applying, students are trained to apply concepts to solve
mathematical problems and problems from the daily lives of students; (d) cooperating, students are
trained to make agreements to determine the best solution. If there are differences in the answers /
solutions to a problem on individual tasks or group assignments then each group member must play an
active role in achieving learning objectives; (e) transferring, students use the knowledge they have in a
new context through the application of concepts obtained either in Mathematics problems or in real life
related to Yogyakarta batik motifs.
Keywords: connecting mathematical ability, REACT stategy, batik motif media

\section{PENDAHULUAN}

National Council of Teachers of Mathematics (NCTM, 2000) menyebutkan bahwa terdapat lima kemampuan dasar Matematika yang menjadi standar yaitu pemecahan masalah (problem solving), penalaran dan pembuktian (reasoning and proof), komunikasi (communication), koneksi (connections), dan representasi (representation). Hal tersebut selaras dengan tujuan pembelajaran 
Matematika yang ditetapkan dalam kurikulum 2013 dalam Permendikbud Nomor 58 tahun 2016 tentang Pedoman Mata Pelajaran Matematika adalah pembelajaran Matematika tidak hanya dimaksud untuk penguasaan materi Matematika sebagai ilmu saja tetapi untuk tujuan penguasaan akan kecakapan Matematika (Mathematical literacy) yang diperlukan untuk memahami dunia sekitar serta untuk keberhasilan dalam kehidupan peserta didik.

Kecakapan hidup yang dapat ditumbuhkan melalui pembelajaran Matematika sebagaimana yang tercantum dalam Permendikbud Nomor 58 tahun 2016 dan Permendikbud Nomor 21 tahun 2016 tentang Standar Isi adalah menggunakan kemampuan berpikir dan bernalar dalam pemecahan masalah, mengkomunikasikan gagasan secara efektif, memiliki sikap dan perilaku yang sesuai dengan nilai-nilai Matematika dan pembelajarannya yaitu teliti, taat azas, konsisten, menjunjung tinggi kesepakatan, menghargai perbedaan pendapat, teliti, tangguh, kreatif, dan terbuka.

Koneksi Matematis didasarkan bahwa ilmu Matematika bukan merupakan bagian yang saling terpisah tetapi merupakan satu kesatuan. Selain itu Matematika tidak terpisah dengan ilmu lain juga tidak terpisah dari masalah yang terjadi dalam kehidupan peserta didik.

Bentuk koneksi matematis meliputi aspek koneksi inter topik Matematika yang mengkaitkan antar konsep dalam satu topik, koneksi antar topik dalam Matematika yang mengkaitkan antara materi dalam topik tertentu dengan materi dalam topik lainnya, koneksi antara materi dengan ilmu lain, dan koneksi dengan kehidupan sehari-hari yang mungkin dijumpai peserta didik.

Koneksi matematis terjadi antara Matematika dengan Matematika itu sendiri atau antara Matematika dengan di luar Matematika (Sugiman, 2008: 1). Seorang peserta didik yang mempunyai kemampuan koneksi matematis akan memahami manfaat Matematika dan mampu melihat keterkaitan topik-topik dalam Matematika. Dengan demikian bahwa tanpa koneksi matematis maka peserta didik harus belajar dan mengingat terlalu banyak konsep-konsep dan prosedur yang saling terpisah dalam Matematika (NCTM, 2000:275)

Ketika peserta didik mampu mengkoneksikan ide matematik, pemahaman peserta didik terhadap Matematika menjadi lebih mendalam dan tahan lama (NCTM, 2000:64). Penyelesaian masalah matematika merupakan kegiatan siswa yang membangun koneksi matematis siswa, hal ini terjadi karena dalam menyelesaikan masalah matematika siswa harus mempunyai kemampuan menemukan keterkaitan konsep atau teorema yang digunakan untuk menentukan penyelesaian suatu soal, kemampuan ini dikatakan koneksi matematika (Maisyarah, $\mathrm{R}$ dan Surya, E; 2017: 5).

Dalam penelitian ini indikator kemampuan koneksi matematis yang digunakan mengacu pada NCTM (2000:64) yaitu mengenal dan menggunakan keterhubungan diantara ide-ide Matematika, memahami bagaimana ide-ide Matematika dihubungkan dan dibangun satu sama lain sehingga berkaitan secara lengkap, dan mengenal serta menggunakan Matematika dalam konteks di luar Matematika dengan pengalaman hidup sehari-hari.

Proses dinamakan transformasi jika seluruh titik suatu objek geometri dipindahkan menurut suatu aturan akan didapatkan bayangan dari gambar asli. Setiap titik pada objek asli memiliki pasangan dengan titik pada bayangan. Dalam geometri, transformasi merupakan prosedur spesifik yang memindahkan titik pada bidang ke titik-titik yang berbeda. Pengertian transformasi adalah sebagi berikut.

"Suatu transformasi merupakan sebuah korespondensi satu-satu antara dua himpunan $\mathrm{S}$ dan $\mathrm{S}$ ' sedemikan sehingga setiap titik di himpunan $S$ berkorespondensi dengan satu dan hanya satu titik di himpunan S' yang disebut sebagai peta atau bayangan, serta setiap titik di S' merupakan peta dari satu dan hanya satu titik di S yang dinamakan sebagai prapeta". (Kemendikbud, 2016: 46).

Jika peta kongruen dengan prapeta maka proses ini disebut transformasi isometri (transformasi yang tidak mengubah bentuk) sehingga jarak setiap dua titik pada bangun peta atau bayangan sama dengan jarak setiap dua titik pada bangun prapeta. Transformasi isometri diantaranya adalah transformasi identitas (peta dan prapeta berimpit, translasi (pergeseran), rotasi (perputaran), dan refleksi (pencerminan). Transformasi yang merubah jarak atau bentuk (transformasi non isometri) 
yang dipelajari oleh peserta didik hanyalah dilatasi (perbesaran). Masih terdapat transformasi non isometri lainnya yaitu stretch (regangan) dan shear (gusuran) akan tetapi materi ini dalam kurikulum 2013 tidak dibelajarkan kepada peserta didik.

Transformasi Geometri dipelajari peserta didik pada saat kelas XI merupakan bagian dari mata pelajaran umum kelompok A sehingga wajib diikuti oleh semua peserta didik baik yang mengambil peminatan MIPA maupun IPS. Menjadi masalah yang setiap tahun muncul bahwa ketika peserta didik berada di kelas XII dan pendidik melakukan tinjauan ulang tentang Transformasi Geometri maka peserta didik hanya akan mengingat bagian dari materi tersebut yaitu Translasi, Refleksi, Rotasi, dan Dilatasi. Keluhan yang mereka sampaikan adalah lupa karena banyak rumus yang ada dalam Transformasi Geometri. Berdasar pada kenyataan itu selama ini peserta didik dalam mempelajari Transformasi Geometri belum bermakna mereka hanya menghafalkan rumus yang segera dapat dilupakan. Mereka tidak dapat mengingat dalam waktu yang panjang. Konsep, prinsip dan keterampilan yang telah mereka dapatkan selama belajar Transformasi Geometri terlupakan tertimbun materi lain dan tidak mudah "dipanggil kembali" pada saat dibutuhkan.

Kegiatan yang dilakukan pendidik sebagai fasilitator adalah menyediakan lingkungan belajar yang menyenangkan, aktif dan kreatif bagi peserta didik agar pembelajaran dapat mencapai tujuan seperti yang diharapkan secara efisien, efektif dan mendapatkan hasil yang maksimal.

Pembelajaran akan menghasilkan hasil belajar yang maksimal apabila pendidik dapat memilih strategi yang tepat disesuaikan dengan kurikulum, materi ajar, fasilitas, karakteristik peserta didik, kemampuan peserta didik, serta kondisi peserta didik baik secara individual maupun kelompok.

Pendekatan pembelajaran yang dimulai dari hal-hal nyata atau sering dialami oleh peserta didik menyebabkan peserta didik dapat segera memahami kegunaan Matematika. Pendidik tidak lagi dihadapkan dengan pertanyaan dari peserta didik tentang mengapa mempelajari materi tersebut atau apa gunanya mereka mempelajarinya. Hal ini akan menyebabkan peserta didik merasa nyaman dan akan menjadi lebih termotivasi untuk belajar karena pembelajaran yang dilakukan bermakna dan berguna bagi mereka. Strategi pembelajaran kontekstual REACT dapat menjadi salah satu pilihan pendidik karena dapat meningkatkan motivasi dan hasil belajar Matematika dan Sains peserta didik (Crawford, 2001: iii). Menurut Crawford (2001: iii) bahwa lima strategi dalam pembelajaran kontekstual yaitu Relating, Experiencing, Applying, Cooperating, dan Transferring yang disingkat menjadi REACT.

Relating (keterkaitan) adalah belajar dalam konteks pengetahuan atau pengalaman yang telah dimiliki peserta didik sebelumnya. Selama tahap ini pendidik mengawali dengan berbagai pertanyaan yang akan dapat dijawab oleh hampir semua peserta didik. Pendidik akan memberikan masalah dalam kehidupan sehari-hari yang berhubungan dengan konsep tersebut. Pendidik juga akan mengaitkan konsep yang akan dipelajari dengan pengetahuan yang sebelumnya telah dimiliki peserta didik.

Experiencing (mengalami) adalah proses peserta didik belajar dengan eksplorasi melakukan berbagai aktivitas yang menitikberatkan pada keaktivan untuk membangun konsep yang baru melalui eksplorasi dan penemuan. Pendidik menyiapkan aktivitas yang sesuai bagi peserta didik misalnya memanipulasi model atau alat peraga untuk menemukan suatu konsep. Pendidik memberikan kebebasan pada peserta didik untuk membangun pengetahuan baru dengan merancang suatu kegiatan yang memberikan pengalaman kepada peserta didik.

Applying (menerapkan) merupakan tahap peserta didik menerapkan konsep yang telah diperoleh dalam kegiatan pemecahan masalah. Tahapan ini bertujuan untuk mengembangkan pemaknaan dalam pembelajaran. Konsep yang telah dipelajari peserta didik diterapkan dan dikembangkan pada keadaan lain. Pendidik memberikan tugas atau latihan yang realistik dan relevan untuk memperdalam pemahaman peserta didik. Menurut Crawford (2001: 16) suatu penelitian menunjukan bahwa latihan soal yang realistik dan relevan dapat memotivasi peserta didik untuk memahami konsep. Latihan soal yang diberikan haruslah sesuai dengan perkembangan intelektual peserta didik dalam arti tidak terlalu sulit ataupun terlalu mudah.

Cooperating (bekerja sama) merupakan tahapan pembelajaran peserta didik saling 
berbagi, bertukar pendapat, maupun berdiskusi dengan peserta didik lainnya. Dalam pembelajaran sering dijumpai bahwa peserta didik mengalami kesulitan bila ia harus melakukan secara individu berbagai kegiatan dalam menemukan konsep ataupun memecahkan masalah. Bekerja dalam kelompok dapat meminimalisir kejadian ini. Peserta didik bersama temannya bertukar pendapat, mengutarakan ide, dan mendapat umpan balik dan bekerja sama menyelesaikan masalah yang semula sukar apabila dikerjakan sendiri. Slavin (2010: 3) mengemukakan bahwa dalam pembelajaran berkelompok peserta didik akan saling membantu, saling mendiskusikan dan berargumentasi, untuk mengasah pengetahuan yang mereka kuasai saat itu. Belajar kooperatif peserta didik belajar bersama, menyumbang pikiran dan bertanggung jawab terhadap pencapaian hasil belajar secara individu maupun kelompok.

Transferring (mentrasfer) merupakan tahapan dimana pengetahuan yang dimiliki peserta didik akan digunakan dalam konteks baru. Dalam tahap ini rasa ingin tahu serta rasa tertantang pada diri peserta didik diharapkan akan muncul apabila dihadapkan pada permasalahan yang baru atau tidak biasa bagi mereka. Proses ini merupakan pengembangan dari relating. Pada tahap ini pembelajaran diarahkan untuk menganalisis dan memecahkan masalah baru dengan menggunakan konsep yang telah diperoleh. Pendidik dapat memberikan permasalahan yang baru dan bervariasi untuk meningkatkan motivasi, keterlibatan, dan minat peserta didik dengan menekankan aspek kerja sama untuk mengembangkan pengetahuan melalui diskusi dalam kelompok ataupun kelas.

Media berarti pengantar atau perantara menunjuk adanya sesuatu yang membawa informasi antara sumber (pengirim pesan) dan penerima pesan (Smaldino dkk; 2005:9-10). Menurut Smaldino dkk (2005: 9-10) terdapat enam jenis media yang dapat digunakan dalam pembelajaran yaitu teks, audio, visual, media bergerak, media yang dapat dimanipulasi, dan orang.

Media berupa teks adalah karakterkarakter alphanumeric (angka dan abjad) yang mungkin ditampilkan dalam berbagai format misal buku, poster, papan tulis, layar komputer, maupun artikel dari internet. Audio (suara) mencakup segala bentuk yang dapat didengar misal suara orang, musik, suara mekanis dan sebagainya. Visual digunakan untuk mempromosikan pembelajaran meliputi poster, gambar pada papan tulis, foto, grafik pada buku, gambar kartun dan sebagainya. Media bergerak mencakup video, animasi, youtube dan sebagainya. Media yang dapat dimanipulasi berupa objek 3-dimensi dapat disentuh dan dipegang oleh peserta didik sebagai contoh kerangka kubus, permainan locat katak, menara Hanoi, Galton Board dan sebagainya. Orang adalah perantara penyampaian pesan sehingga termasuk dalam media pembelajaran. Mereka adalah pendidik, siswa atau pakar di bidang tertentu (SMESubject Matter Expert). Peserta didik dapat belajar dari pendidik, peserta didik lain, atau orang dewasa lain.

Peraturan Gubernur DIY Nomor 66 Tahun 2013 tentang Kurikulum Pendidikan Berbasis Budaya menyebutkan bahwa agar pendidikan dapat memberikan sumbangan strategis dalam konteks kebudayaan ada dua hal yang dapat diindentifikasi yaitu di satuan pendidikan dan dalam materi pembelajaran. Satuan pendidikan harus melaksanakan pendidikan yang dinamis dan kreatif melibatkan kemampuan memperoleh informasi, bagaimana mengolah informasi, dan menyikapi informasi tersebut secara kreatif. Materi pembelajaran berupa materi yang berpotensi membuat peserta didik lebih kritis dan peka terhadap terhadap situasi kehidupan.

Semboyan yang digunakan dalam melakukan pembelajaran dalam kurikulum berbasis badaya adalah "dekatkan anak didik dengan lingkungan dan jangan mengasingkannya". Pendidik hendaknya mengupayakan pemilihan bahan pendidikan yang bersifat "lokal". Salah satu yang dapat menjadi alternatif adalah batik.

Batik adalah bagian artefak berupa karya seni budaya yang sarat dengan nilai-nilai luhur yang belakangan ini mulai pudar pemahamannya disebagian kalangan anak muda. Mereka tidak lagi memahami siapa saja yang boleh menggunakan motif tertentu, kapan, bagaimana suatu motif batik tepat digunakan, dan apa filosofi dibalik motif batik. Peserta didik sebagai bagian masyarakat Yogyakarta diharapkan dapat berperan aktif dalam upaya pelestarian budaya melalui kegiatan terintegrasi ke dalam mata pelajaran Matematika. Berdasarkan hal tersebut maka dalam penelitian ini menggunakan media batik gaya Yogyakarta. 
Sejarah batik Yogyakarta dapat dirunut dari Perjanjian Giyanti tahun 1755 menyebabkan Mataram terbagi dua yaitu menjadi Surakarta dan Ngayogyakarta. Pangeran Mangkubumi berkehendak melestarikan sehingga busana Mataram diangkut dari Surakarta ke Ngayogyakarta. Kurun waktu yang panjang membuktikan bahwa Yogyakarta akhirnya menjadi kota pusat tradisi batik dan pusat penciptaan seni batik.

Pengertian batik dalam situs Karaton Ngayogyakarta Hadiningrat adalah sebagai berikut.

\begin{abstract}
"Kata batik dalam bahasa Jawa berasal dari akar kata tik yang merujuk pada pekerjaan tangan yang halus, lembut, dan detil, yang mengandung unsur keindahan (seni). Kata tik juga merujuk pada proses pembuatan corak kain dengan 'menitikkan' malam (lilin) dengan alat bernama canting sehingga membentuk corak yang terdiri atas susunan titikan dan goresan"
\end{abstract}

Selain itu dalam situs tersebut menyebutkan bahwa:

"Makna batik sendiri bisa mengacu pada dua hal. Mengacu pada teknik pembuatan, batik adalah teknik pewarnaan yang menggunakan malam sebagai perintang bahan pewarna pada kain (wax-resist dyeing). Mengacu pada motif dan pola, batik adalah kain atau busana yang dibuat dengan teknik tersebut, dan memiliki motif-motif tertentu yang khas"

Pengertian lain dari kata "batik" berasal dari gabungan dua kata dalam bahasa Jawa "amba" yang bermakna "menulis" dan "titik" yang bermakna "titik". Kata batik pada umumnya merujuk pada kain dengan corak yang dihasilkan oleh bahan "malam" yang diaplikasikan di atas kain sehingga menahan masuknya bahan pewarna (https://kebudayaan.kemdikbud.go.id).

Batik tidak hanya berkembang di Yogyakarta tetapi di seluruh wilayah Nusantara. Berbagai daerah mempunyai motif maupun teknik pembuatan yang akhirnya dikenal sebagai ciri khas daerah asal batik. Penetapan UNESCO pada 2 Oktober 2009 bahwa batik merupakan salah satu warisan kemanusiaan untuk karya lisan dan non bendawi (Masterpieces of the Oral and Intangible Heritage of Humanity) telah menjadi pengakuan dunia tentang batik diakui sebagai warisan budaya yang berasal dari Indonesia (https://nasional.kompas.com).

Dari begitu banyak kota di Indonesia memiliki batik yang merupakan kekhasan daerah tersebut hanya Yogyakarta yang mendapat penghargaan tingkat dunia tentang batik. Penobatan Yogyakarta sebagai Kota Batik Dunia oleh World Craft Council (Dewan Kerajinan Dunia) telah menambah keistimewaan Yogyakarta. Penghargaan tersebut dinyatakan dalam bentuk pemberian Plakat Pengakuan yang diserahkan oleh WCC pada peringatan 50 tahun organisasi tersebut di Dongyang, Provinsi Zhejiang Tiongkok pada tanggal 18 sampai dengan 23 Oktober 2014 (http://travel.kompas.com).

Batik Yogyakarta berbeda dengan batik lain. Perbedaan ini dapat dengan mudah dikenali. Ciri khas batik Yogyakarta ada pada latar dan warna batik. Dua macam latar atau warna dasar kain pada batik Yogyakarta adalah putih atau hitam (biru kehitaman). Warna batik putih merupakan warna dari kain mori atau biru tua kehitaman dan coklat soga. Warna dalam batik Yogyakarta cenderung mengarah ke warna-warna tanah tidak lepas dari pengaruh geografis dan lingkungan sekitar. Warna-warna tersebut memiliki makna simbolis. Dalam situs Karaton Ngayogyakarta Hadiningrat disebutkan simbol warna dalam batik. Coklat adalah simbol untuk tanah lempung yang subur diharapkan dapat membangkitkan rasa kebahagiaan, rendah hati, dan kesederhanaan. Biru merupakan simbol ketenangan, kepercayaan, kelembutan pekerti, keikhlasan, dan kesetiaan. Putih melambangkan sinar kehidupan, kesucian, ketenteraman hati, keberanian dan sifat pemaaf bagi yang memakai. Warna hitam atau gelap melambangkan kekuatan, kekekalan, kemewahan, misterius dan keanggunan (www.kratonjogja.id).

Keunikan batik terletak pada motif, pakem (cara mengorganisasi motif), dan isenisen (ornamen kecil yang digunakan untuk mengisi ruang kosong diantara motif utama). Batik memiliki berbagai macam motif yang bervariasi. Motif atau corak batik atau pola batik khas Yogyakarta dapat berbentuk geometris maupun non geometris. Ada tiga 
kelompok motif geometris yaitu motif Parang, Ceplok dan Lereng. Sedangkan motif non geometris antara lain motif Semen, Lunglungan, dan Boketan.

Dalam penelitian ini media yang digunakan adalah media visual berupa Lembar Kegiatan Peserta Didik berisi beberapa motif batik geometris Yogyakarta dan keterkaitan budaya atau filosofi batik tersebut.

\section{METODE PENELITIAN}

\section{Jenis Penelitian}

Penelitian ini merupakan penelitian kualitatif berupa Penelitian Tindakan Kelas (PTK).

\section{Waktu dan Tempat Penelitian}

Penelitian ini dilaksanakan pada bulan Okotober sampai dengan Desember 2019 di SMA Negeri 7 Yogyakarta yang beralamat di Jalan MT. Haryono No.47 Yogyakarta. Sekolah tersebut telah terakreditasi A.

\section{Subjek Penelitian}

Subjek penelitian ini adalah peserta didik kelas XI IPS 1 SMA Negeri 7 Yogyakarta Tahun Pelajaran 2019/2020. Jumlah peserta didik 32 orang terdiri atas 10 peserta didik laki-laki dan 22 peserta didik perempuan.

\section{Prosedur}

Penelitian direncanakan dalam beberapa siklus, sampai target atau indikator keberhasilan yang diharapkan tercapai. Apabila hasil yang diperoleh belum memenuhi indikator keberhasilan yang telah ditetapkan, maka tindakan dilanjutkan untuk siklus berikutnya. Siklus akan berakhir jika hasil penelitian yang diperoleh sudah sesuai dengan indikator keberhasilan penelitian. Penelitian ini menggunakan model spiral Kemmis dan Taggart yang dikembangkan oleh Stephen Kemmis dan Robin Mc Taggart (2014:19).

\section{Instrumen dan Teknik Pengumpulan Data}

Teknik pengumpulan data yang dilakukan dalam penelitian ini dilakukan dengan menggunakan tes dan non tes. Instrumen tes berupa tes tertulis digunakan untuk memperoleh data tentang prestasi belajar peserta didik. Sedangkan instrumen non tes digunakan untuk mengukur keterlaksanaan pembelajaran, mengukur capaian peserta didik dalam menyelesaikan tugas, presentasi hasil kerja, serta dokumentasi.
Instrumen tes prestasi belajar digunakan untuk mengukur ketuntasan belajar peserta didik baik secara individu maupun klasikal dan untuk mengetahui ketercapaian kompetensi dasar Transformasi Geometri. Hasil tes juga digunakan untuk mengetahui peningkatan hasil belajar peserta didik pada setiap siklus. Instrumen tes yang digunakan adalah soal tes pilihan ganda dengan lima pilihan yang terdiri atas 25 item. Tes dilaksanakan pada setiap akhir siklus.

Instrumen non tes berupa lembar observasi keterlaksanaan pembelajaran terdiri atas dua bagian meliputi keterlaksanaan pembelajaran oleh pendidik dan keterlaksanaan pembelajaran oleh peserta didik. Lembar observasi keterlaksanaan pembelajaran oleh pendidik digunakan untuk mengumpulkan data keterlaksanaan pembelajaran yang dilakukan oleh pendidik melalui penerapan strategi REACT. Pengumpulan data tentang kegiatan peserta didik selama pembelajaran menggunakan lembar observasi keterlaksanaan pembelajaran oleh peserta didik. Lembar observasi ini mempunyai dua skala penilaian yaitu "ya" atau "tidak". Pilihan "ya" digunakan jika pendidik atau peserta didik melaksanakan kegiatan yang tercantum pada lembar observasi, sedangkan pilihan "tidak" digunakan jika pendidik atau peserta didik belum melaksanakan kegiatan yang tercantum pada lembar observasi.

Instrumen yang digunakan dalam penilaian tugas berupa Lembar Kerja Peserta Didik (LKPD) untuk setiap siklus. Peserta didik mendapatkan beberapa motif batik yang akan dianalisis aspek Tranformasi Geometri yang termuat dalam motif tersebut kemudian menambahkan keterkaitan budaya atau filosofi dari motif itu. Selain itu peserta didik ditugasi untuk menambahkan beberapa motif, menganalisis aspek Transformasi Geometri yang terkandung, keterkaitan budaya atau filosofi dari motif yang mereka pilih. Kriteria predikat yang digunakan seperti dalam KTSP SMA Negeri 7.

Lembar penilaian unjuk kerja yang dilaksanakan oleh peserta didik berupa presentasi tentang tugas yang diselesaikan. Lembar observasi ini memuat indikator topik presentasi, penguasaan materi, kelengkapan materi, kebenaran isi presentasi, sistematika, penggunaan bahasa. Lembar penilaian presentasi dilengkapi dengan deskripsi dalam 
skala 1 sampai dengan 4. Hasil tersebut kemudian dikonversi ke dalam nilai. Kriteria predikat yang digunakan seperti dalam KTSP SMA Negeri 7.

Selama proses pembelajaran berlangsung dokumen foto dan video digunakan untuk mendapatkan gambaran visualisasi aktivitas pendidik dan peserta didik dalam pembelajaran.

\section{Teknik Analisis Data}

Teknis analisis data dalam PTK ini terdiri atas analisis data secara kualitatif dan kuantitatif. Analisis data secara kualitatif untuk mendeskripsikan proses pelaksanaan tindakan dan hasil temuan di kelas. Analisis data secara kuantitatif digunakan untuk menganalisis data berupa skor atau nilai yang diperoleh dari pengumpulan data.

Analisis data yang digunakan untuk mengukur prestasi belajar peserta didik adalah analisis data ketuntasan belajar secara deskriptif menggambarkan capaian peserta didik baik secara individual maupun secara klasikal. Analisis secara individual yaitu dengan menghitung nilai capaian masingmasing peserta didik. Peserta didik dinyatakan tuntas apabila telah mencapai minimal 75 . Sedangkan analisis ketuntasan secara klasikal dilakukan dengan menggunakan rumus:

Keterangan:

$$
K K=\frac{X}{Z} \times 100 \%
$$

$K K=$ ketuntasan klasikal

$X=$ jumlah peserta didik yang mendapat nilai lebih dari sama dengan 75

$Z \quad$ = jumlah peserta didik keseluruhan

Adanya peningkatan prestasi belajar peserta didik dilakukan dengan cara membandingkan prosentase ketuntasan klasikal pada setiap siklus. Selain itu juga digunakan untuk melihat keefektifan proses pembelajaran. Hasil pada tes akhir siklus I dan tes akhir siklus II dibandingkan apabila terdapat peningkatan maka proses pembelajaran dikatakan efektif.

Analisis hasil observasi keterlaksanaan pembelajaran dengan menghitung prosentase keterlaksanaan menggunakan rumus berikut.

Keterangan:

$$
P=\frac{M}{T} \times 100 \%
$$

$P=$ Presentase keterlaksanaan pembelajaran

$M=$ Frekuensi item terlaksana

$T=$ Total item terlaksana

\section{HASIL DAN PEMBAHASAN}

Setelah dilakukan penelitian tindakan kelas, terdapat peningkatan koneksi matematis dilihat dari aspek koneksi inter topik Matematika yang mengkaitkan antar konsep dalam satu topik dan koneksi antar topik dalam Matematika yang mengkaitkan antara materi dalam topik tertentu dengan materi dalam topik lainnya. Data tersebut diperoleh dari hasil tes yang dikerjakan peserta didik pada setiap akhir siklus. Hasil peningkatan ini dapat dilihat pada gambar berikut.

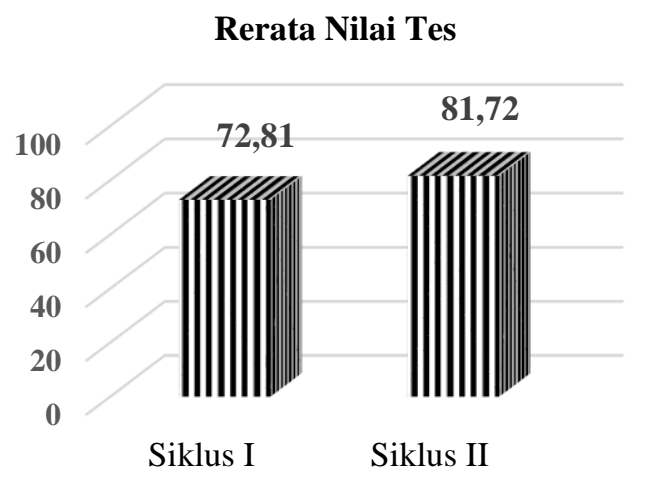

Gambar 1. Rerata Nilai Tes Peserta Didik dari Setiap Akhir Siklus

Tes pada akhir siklus I dan siklus II pada penelitian ini menghasilkan kenaikan rerata nilai tes. Data standar deviasi perolehan nilai peserta didik dari akhir siklus I adalah 11.30 dan dari hasil tes akhir siklus II adalah 6.33. Hasil ini menunjukkan bahwa hasil tes akhir siklus I lebih beragam bila dibandingkan dengan hasil tes dari akhir siklus II. Target rerata nilai tes peserta didik dalam penelitian ini adalah minimal 75 sehingga hasil rerata tes pada akhir siklus II telah melampaui target.

\section{Nilai Tertinggi dan Nilai Terendah}

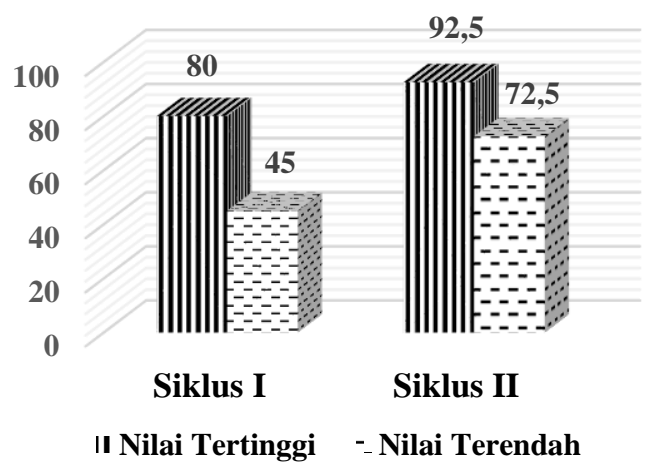

Gambar 2. Nilai Tertinggi dan Nilai Terendah dari Setiap Akhir Siklus

Data yang menyajikan hasil pada setiap akhir siklus dalam gambar tersebut tampak bahwa terdapat kenaikan baik dalam nilai 
tertinggi maupun nilai terendah. Hasil tes pada akhir siklus I terdapat dua peserta didik mendapatkan nilai terendah 45 dan 16 peserta didik mendapat nilai tertinggi. Sedangkan pada hasil akhir siklus II terdapat lima peserta didik mendapatkan nilai terendah 72.5 dan 16 peserta didik mendapat nilai tertinggi empat peserta didik mendapat nilai tertinggi 92.5.

\section{Persentase Ketuntasan}

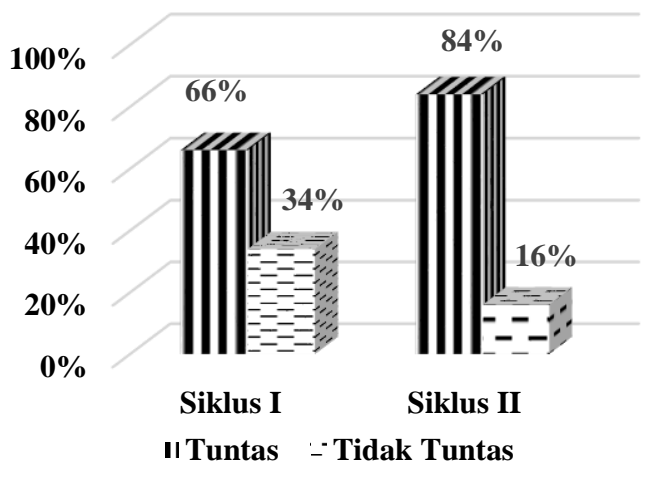

Gambar 3. Persentase Ketuntasan Peserta

Didik dari Setiap Akhir Siklus

Setiap akhir siklus dilaksanakan tes yang diikuti oleh seluruh peserta didik yang berjumah 32 orang. Hasil tes pada akhir siklus I terdapat 21 peserta didik tuntas dan 11 belum tuntas. Terdapat kenaikan pada persertase ketuntasan dari hasil tes pada akhir siklus II yaitu 27 peserta didik telah tuntas dan masih terdapat 5 peserta didik belum tuntas. Hasil pada akhir siklus II telah melampaui target yaitu $75 \%$ peserta didik telah tuntas.

\section{Rerata Nilai Tugas}

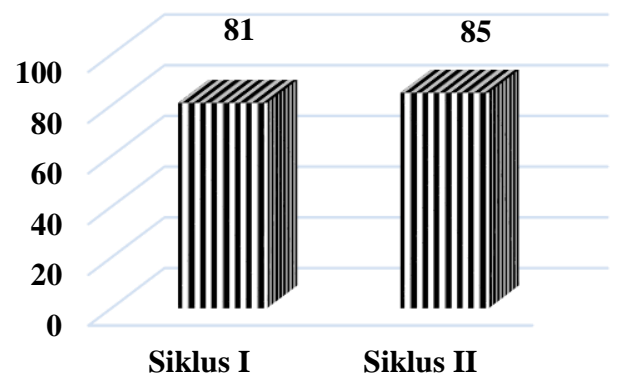

\section{Gambar 5. Rerata Nilai Tugas Kelompok}

Terjadi peningkatan rerata nilai tugas kelompok peserta didik. Pada siklus I rerata nilai tugas kelompok adalah 81 . Hal ini berarti apabila menggunakan ketuntasan penugasan dalam KTSP SMA Negeri 7 hasil tersebut masih dalam kategori cukup. Sedangkan hasil pada siklus II rerata nilai tugas naik menjadi 85 yang berarti telah masuk kategori baik.

\section{Rerata Nilai Presentasi}

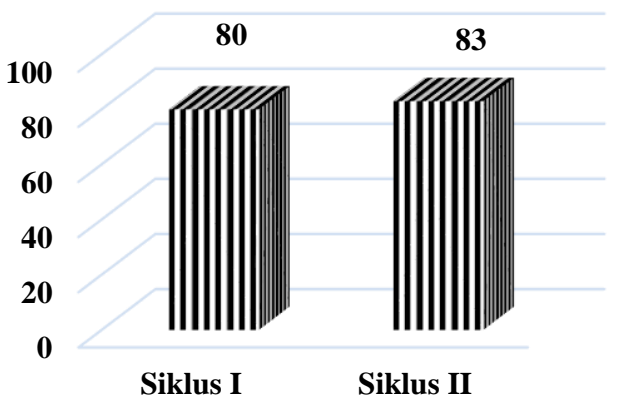

Gambar 6. Rerata Nilai Presentasi pada Tiap Siklus

Data tentang nilai presentasi menunjukkan adanya peningkatan rerata nilai peserta didik. Pada siklus I menghasilkan rerata nilai 80 apabila menggunakan ketuntasan penugasan dalam KTSP SMA Negeri 7 hasil tersebut masih dalam kategori cukup. Sedangkan hasil pada siklus II rerata nilai presentasi telah naik menjadi 83 yang berarti telah masuk kategori baik.

Tabel 1. Hasil Rerata Prosentase Keterlaksanaan Pembelajaran Pendidik dan Peserta Didik

\begin{tabular}{clcc}
\hline No & \multicolumn{1}{c}{ Hasil Analisis } & Siklus I & Siklus II \\
\hline 1 & $\begin{array}{l}\text { Keterlaksanaan } \\
\text { Pembelajaran oleh }\end{array}$ & 89 & 91 \\
2 & $\begin{array}{l}\text { Pendidik } \\
\text { Keterlaksanaan } \\
\text { Pembelajaran oleh } \\
\text { Peserta Didik }\end{array}$ & 88 & 91 \\
\hline
\end{tabular}

Berdasarkan hasil lembar observasi kegiatan pendidik maupun peserta didik diperoleh hasil bahwa pelaksanaan pembelajaran menggunakan strategi REACT berbantu media motif batik terdapat peningkatan dari siklus I ke siklus II. Prosentase pada siklus II telah melebihi target dalam indikator keberhasilan yaitu minimal 90\% telah terlaksana dalam proses pembelajaran.

\section{SIMPULAN}

Untuk meningkatkan koneksi matematis peserta didik dapat dilakukan dengan cara: (a) relating yaitu pendidik memberikan kesempatan kepada peserta untuk mengaitkan materi yang dipelajari dalam Transformasi Geometri dengan kehidupan sehari-hari melalui contoh yang nyata dalam LKPD yang memuat motif geometri yang terkandung dalam batik Yogyakarta. Dalam proses ini pendidik mendorong setiap peserta didik untuk mengemukakan pendapat dalam menyelesaikan masalah, baik secara tertulis 
maupun lisan; (b) experiencing yaitu membiasakan peserta didik untuk membangun pengetahuan/ konsep sendiri yang terkait dengan Transformasi Geometri melalui proses kegiatan belajar dan materi ajar yang disiapkan oleh pendidik; (c) applying yaitu peserta didik dilatih untuk menerapkan konsep untuk menyelesaikan suatu masalah Matematika maupun masalah dari kehidupan sehari-hari peserta didik melalui media batik Yogyakarta; (d) cooperating yaitu peserta didik belajar secara berkelompok terdiri dari keragaman tingkat kemampuan pengetahuan maupun keterampilan. Peserta didik dilatih membuat kesepakatan untuk menentukan jawaban/penyelesaian terbaik. Jika terdapat perbedaan jawaban/penyelesaian dari suatu masalah pada tugas individu atau tugas kelompok maka setiap anggota kelompok harus berperan aktif dalam mencapai tujuan pembelajaran; (e) transferring yaitu peserta didik menggunakan pengetahuan yang dimilikinya dalam situasi dan konteks yang baru melalui penerapan konsep yang diperoleh baik dalam masalah Matematika atau dalam kehidupan nyata dikaitkan dengan motif batik Yogyakarta.

\section{DAFTAR PUSTAKA}

BNPB D.I. Yogyakarta. Batik: Sebuah Konsep Estetika Seni Jawa yang Adiluhung, Indah bagai di Awang. Tersedia di https://kebudayaan.kemdikbud.go.id. Diakses pada 20 April 2019 pukul 20.59.

Crawford, M.L. (2001). Teaching Contextually: Research, Rationale, and Techniques for Improving Student Motivation and Achievment in Mathematics and Science. Waco, Texas, USA: CORD CCI Publishing, Ic.

Karaton Ngayogyakarta Hadiningrat. (2019). Sejarah Batik Yogyakarta. Tersedia di https://www.kratonjogja.id/kagungan -dalem/6/sejarah-batik-yogyakarta. Diakses pada 20 Mei 2018 pukul 21.30.

Kemendikbud. (2016). Strategi Pembelajaran 1, Geometri dan Irisan Kerucut. Pendidik Pembelajar Modul Matematika SMA. Jakarta.
Kemmis, S. and Mc Taggart, R. (1988). The Action Research Planner. Victoria: Deakin University.

Kompas.Yogyakarta Dipilih jadi Kota Batik Dunia. Tersedia di http://travel.kompas. com. Diakses pada 10 Juli 2019 pukul 20.00

Kompas. 2 Oktober 2009, UNESCO Akui Batik sebagai Warisan Dunia dari Indonesia. Tersedia di https://nasional. kompas.com. Diakses pada 10 Juli 2019 pukul 21.50.

Maisyarah, Raja dan Surya, E. (2017). Kemampuan Koneksi Matematis (Connecting Mathematics Ability) Siswa dalam Menyelesaikan Masalah Matematika. Tersedia di https:// www.researchgate.net/publication/321803645. Diakses pada 20 Desember 2017 pukul 21.20.

NCTM. (2000). Principles and Standards for School Mathematics. Tersedia di www.nctm.org. Diakses pada 19 Desember 2017 pukul 21.45.

Peraturan Gubernur DIY Nomor 66 Tahun 2013 tentang Kurikulum Pendidikan Berbasis Budaya.

Permendikbud Nomor 21 Tahun 2016 tentang Standar Isi Pendidikan Dasar dan Menengah.

Permendikbud Nomor 58 Tahun 2016 tentang Pedoman Mata Pelajaran Matematika.

Robert E, Slavin. 2010. Cooperative Learning: Teori, Riset, dan Praktik. Terjemahan Narulita Yusron. Bandung: Nusa Media.

Smaldino, S., Russell, J., Heinich, R., Molenda, M. (2005). Instructional Technology and Media for Learning. $\left(8^{\text {th }}\right.$ Ed). New Jersey: Person Merrill Prentice Hall.

Sugiman. (2008). Koneksi Matematik dalam Pembelajaran Matematika di Sekolah Menengah Pertama. Jurusan Pendidikan Matematika FMIPA Universitas Negeri Yogyakarta. 